\title{
Ferronickel Slag Performance from Reclamation Area in Pomalaa, Southeast Sulawesi, Indonesia
}

\author{
Bieby Voijant Tangahu1, IDAA Warmadewanthi', Dian Saptarini², Lily Pudjiastuti ${ }^{3}$, \\ Mas Agus Mardyanto Tardan', Arif Luqman' \\ ${ }^{1}$ Department of Environmental Engineering, Institut Teknologi Sepuluh Nopember, Surabaya, Indonesia \\ ${ }^{2}$ Department of Biology, Institut Teknologi Sepuluh Nopember, Surabaya, Indonesia \\ ${ }^{3}$ Department of Chemical Engineering, Institut Teknologi Sepuluh Nopember, Surabaya, Indonesia \\ Email: voijant@its.ac.id
}

Received 30 June 2015; accepted 24 July 2015; published 28 July 2015

Copyright (C) 2015 by authors and Scientific Research Publishing Inc.

This work is licensed under the Creative Commons Attribution International License (CC BY).

http://creativecommons.org/licenses/by/4.0/

(c) (i) Open Access

\section{Abstract}

This study aimed to assess the differences of characteristics between the new ferronickel slag generated from the production of nickel and the slag which had been used as a material reclamation. The Toxicity Characteristic Leaching Procedure (TCLP) test was conducted on ferronickel slag to determine the concentration of heavy metals leaching. Then, the tests of X-Ray Diffraction (XRD), Scanning Electron Microscopic (SEM) and Energy-Dispersive X-Ray Spectroscopy (EDX) are also conducted on the ferronickel slag samples. The results of TCLP test show that the new ferronickel slag samples contain Fe (158, $6775 \mathrm{ppm}), \mathrm{Cr}(0.64465 \mathrm{ppm})$, and $\mathrm{Pb}(0.0219 \mathrm{ppm})$, and that the ferronickel slag has been used as a reclamation material containing Fe (3.94 ppm) and $\mathrm{Cr}$ (2.91 ppm). The result of EDX test shows that the slag sample from the reclamation area contains higher Ni concentration than the new slag sample. Slag that has been used for reclamation contains high $\mathrm{SiO}_{2}$ and $\mathrm{Mg}_{2}\left(\mathrm{SiO}_{6}\right)$. The XRD analysis result shows that the highest elements in the slag are $\mathrm{Si}$ and $\mathrm{Mg}$ with $\mathbf{1 8 . 9 4 \%}$ and $15.83 \%$ respectively. The dominant mineral in the slag is forsterite $(\mathrm{Mg} 1.784$ $\left.\mathrm{FeSiO}_{4} 0216\right)$ by $41 \%$ and the rest is magnesium silicate $\left(\mathrm{Mg}_{2}\left(\mathrm{Si}_{2} \mathrm{O}_{6}\right)\right)$.

\section{Keywords}

EDX, SEM, Ferronickel Slag, XRD

\section{Introduction}

Industrial process of nickel ore into ferronickel produces slag as a by-product. The percentage of slag generated

How to cite this paper: Tangahu, B.V., Warmadewanthi, I., Saptarini, D., Pudjiastuti, L., Tardan, M.A.M. and Luqman, A. (2015) Ferronickel Slag Performance from Reclamation Area in Pomalaa, Southeast Sulawesi, Indonesia. Advances in Chemical Engineering and Science, 5, 408-412. http://dx.doi.org/10.4236/aces.2015.53041 
in the processing of nickel ore can reach 50\% - 75\% [1]. The study of Demotica et al. [2] mentions that the content of the slag in Illigan City, Philippines contains dominant mineral forsterite in the slag. The dominant mineral and slag structure may differently depend on each type of industry.

On Illigan Bay, Philippines, the ferronickel slag has been used as a material for the reclamation of 20 hectares [2]. In the Illawarra and Newcastle, Australia, slag also has been applied to many fields of infrastructure as a substitute for cement in several years [3]. In addition, in Pomalaa, Southeast Sulawesi, ferronickel slag has also been used as a material reclamation since around year of 1970s. In this study, the characteristic of the slag that has been used as sreclamation material is observed to compare with the new slag.

\section{Research Methods}

\subsection{Analysis of TCLP}

The method used is USEPA Method 1311. A hundred grams of ferronickel slag sample put in the 2.2 L HDPE (high density polyethylene) extraction vessel. Then $2 \mathrm{~L}$ of extraction solution was added with Liquid/solid ratio was $20 \mathrm{~L} / \mathrm{kg}$. The mixture then stirred for $18+2$ hours in the rotary extractor and then the sample was filterred in glass fiber filter using a filter size of $0.7 \mathrm{~lm}$. Then added $1 \mathrm{~N}$ HNO into the filtrate to achieve a $\mathrm{pH}<2$. Analyze the heavy metal component of the filtrate for elements of $\mathrm{Fe}, \mathrm{Cr}$, and $\mathrm{Pb}$ using Inductivvely Couple Plasma (ICP) analyzer.

\subsection{Analysis of SEM}

Macro and microstructure analysis was performed using scanning electron microscopy (SEM JEOL JSM6510LA). The 20 grams of samples were dried to remove the water content, and then crushed sputtering with carbon before analyzed with SEM analyzer.

\subsection{XRD Analysis}

The 20 grams of samples were dried and crushed, then analyze the minerals component in the slag using X-Ray Diffraction (XRD) analyzer and then compared with the standard software Mineral Database from the International Centre for Diffraction Data (ICDD) to determine the type of minerals in the slag.

\subsection{EDX Analysis}

The EDX analysis is to determine the chemical composition of the slag. 20 grams were crushed and analyzed.

\section{Results and Discussion}

\subsection{Analysis of TCLP Test Results}

The TCLP test is conducted to determine the leaching characteristic of slag, which is leaching is one of characteristic of hazardous material. In the TCLP test, the measured heavy metals are $\mathrm{Fe}, \mathrm{Cr}, \mathrm{Cu}, \mathrm{Pb}$, and $\mathrm{Cd}$ with the concentration of Fe, $\mathrm{Cr}$ and $\mathrm{Pb}$ are 6775 ppm, 0.64465 ppm, 0.0219 respectively, which $\mathrm{Cu}$ and $\mathrm{Cd}$ are not detected (Table 1). The content of heavy metals Cr TCLP exceeded the quality standard based on Indonesia Government Regulation No. 18 of the year 1999, which states that the maximum levels of $\mathrm{Cr}$ in the waste extracted is $0.25 \mathrm{ppm}$.

Table 1. Comparison of metals between slag TCLP test results and quality standards.

\begin{tabular}{ccc}
\hline Heavy metals & Concentration $\mathbf{( p p m )}$ & The concentration of each metal in quality standard (ppm) \\
\hline $\mathrm{Fe}(\mathrm{ppm})$ & 6775 & Not listed \\
$\mathrm{Cr}(\mathrm{ppm})$ & 0.64465 & 0.25 \\
$\mathrm{Cu}(\mathrm{ppm})$ & Not detected & 0.19 \\
$\mathrm{~Pb}(\mathrm{ppm})$ & 0.0219 & 2.5 \\
$\mathrm{Cd}(\mathrm{ppm})$ & Not detected & 0.05 \\
\hline
\end{tabular}




\subsection{Slag Characteristics}

Slag characteristics in this study were tested to determine the elements contained in the microscopic structure of the slag. This analysis is very important to know the physical and chemical characteristics of the slag. The results of SEM and EDX are shown in Figure 1, it can be seen that the highest element in the slag are Si and Mg with percentages of $18.94 \%$ and $15.83 \%$ respectively, followed by $\mathrm{Fe}$ and Ni, each with percentage of $5.84 \%$ and $0.014 \%$ respectively. Toxic heavy metals such as $\mathrm{Cu}, \mathrm{Cr}, \mathrm{Pb}$ and $\mathrm{Co}$ are in a very small percentage. Even $\mathrm{Pb}$ is not detected in the slag samples.

In contrast, the test results of the slag sample from the reclamation area which is mixed with the soil around the site is contained with higher concentration of Fe and Ni than the slag on top (Figure 2).

These results also prove that the soil around the site is contained with $\mathrm{Ni}$ in high concentration. The percentage of $\mathrm{Ni}$ in the sample of new slag is much lower compare with slag sample from reclamation area which is mix with soil. The previous study of Demotica et al. (2012) that examined the ferronickel slag in Iligan City, Philippines found that the slag composition were contained with high of Si, Mg and Al.

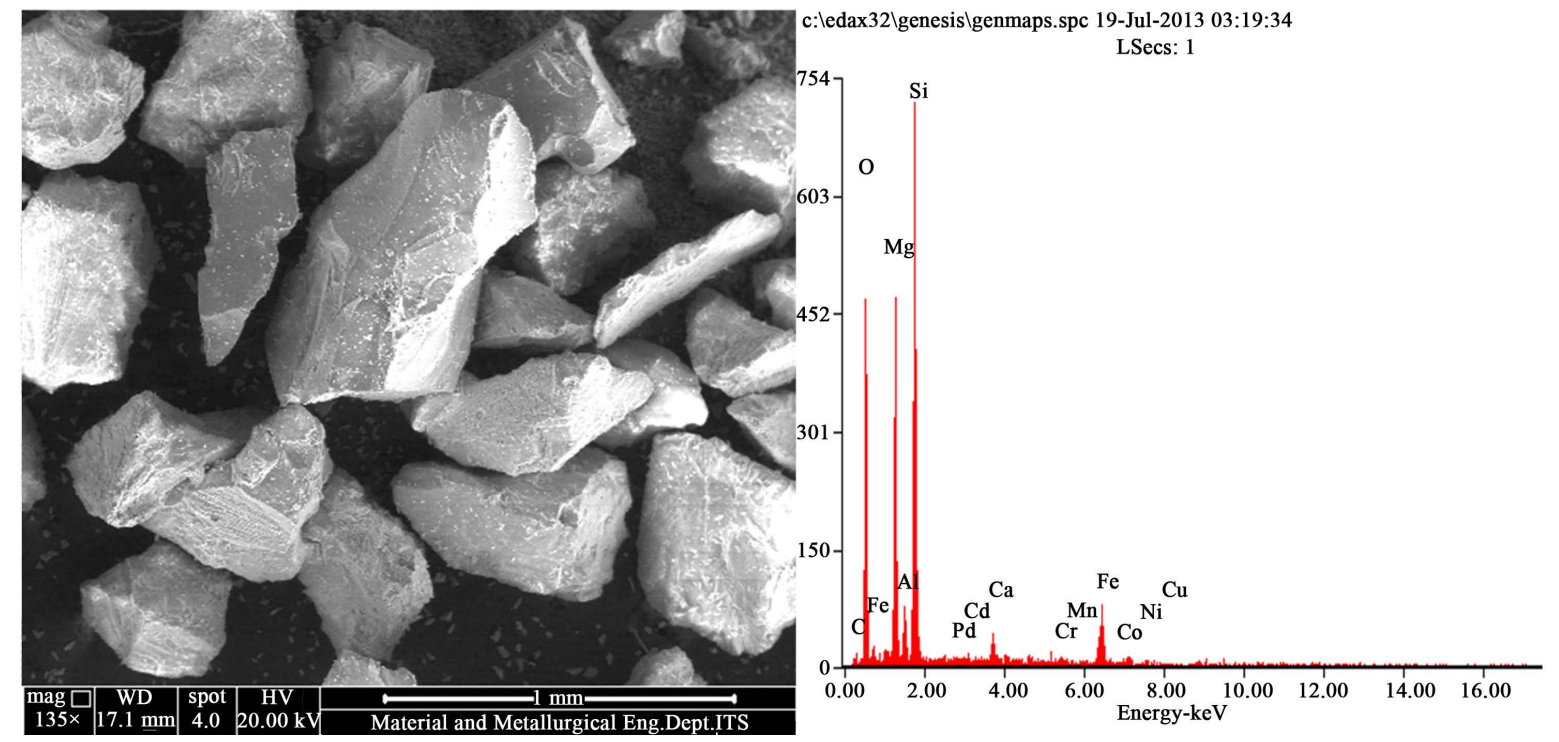

Figure1. The results of SEM and EDX tests of the new slag sample.

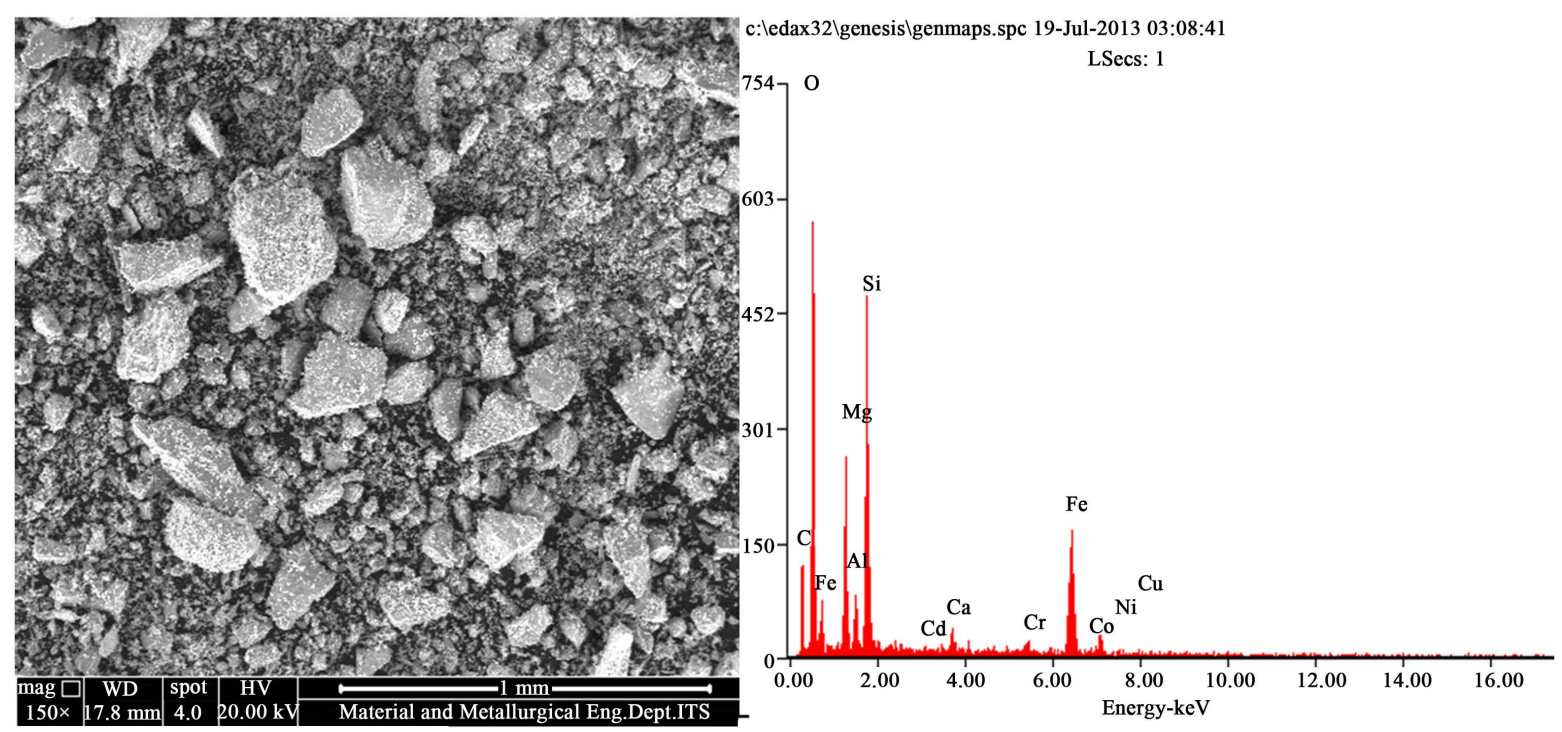

Figure 2. The results of SEM and EDX tests of the slag sample from reclamation area. 
The XRD analysis was conducted to examine the dominant minerals present in the slag. The result shows that the dominant mineral present in the slag is forsterite $\left(\mathrm{Mg} 1.784 \mathrm{Fe} 0216 \mathrm{SiO}_{4}\right)$ and magnesium silicate $\left(\mathrm{Mg}_{2}\left(\mathrm{Si}_{2} \mathrm{O}_{6}\right)\right.$. The forsterite in the mineral is $41 \%$ while the rest is magnesium silicate. This result is similar to the study conducted by Demotica et al. (2012), that the dominant mineral in the slag is forsterite. The presence of high $\mathrm{Si}$ in the slag is made the slag very strong and bonded with calcium-based mineral (Rasio $1 / 2 \mathrm{H}_{2} \mathrm{O}_{4}$ ) and with this characteristic the slag can be used for material in carbonication mineral element that is used to absorb carbon. The XRD results for new slag sample is shown in Figure 3, while the XRD result of slag sample from reclamation area is shown in Figure 4.

Slag sample from reclamation area is contain with high percentage of $\mathrm{SiO}_{2}$ and $\mathrm{Mg}_{2}\left(\mathrm{SiO}_{6}\right)$. This because the slag has been mixed with the soil in the area of reclamation and the most major minerals in the soil is $\mathrm{SiO}_{2}$.

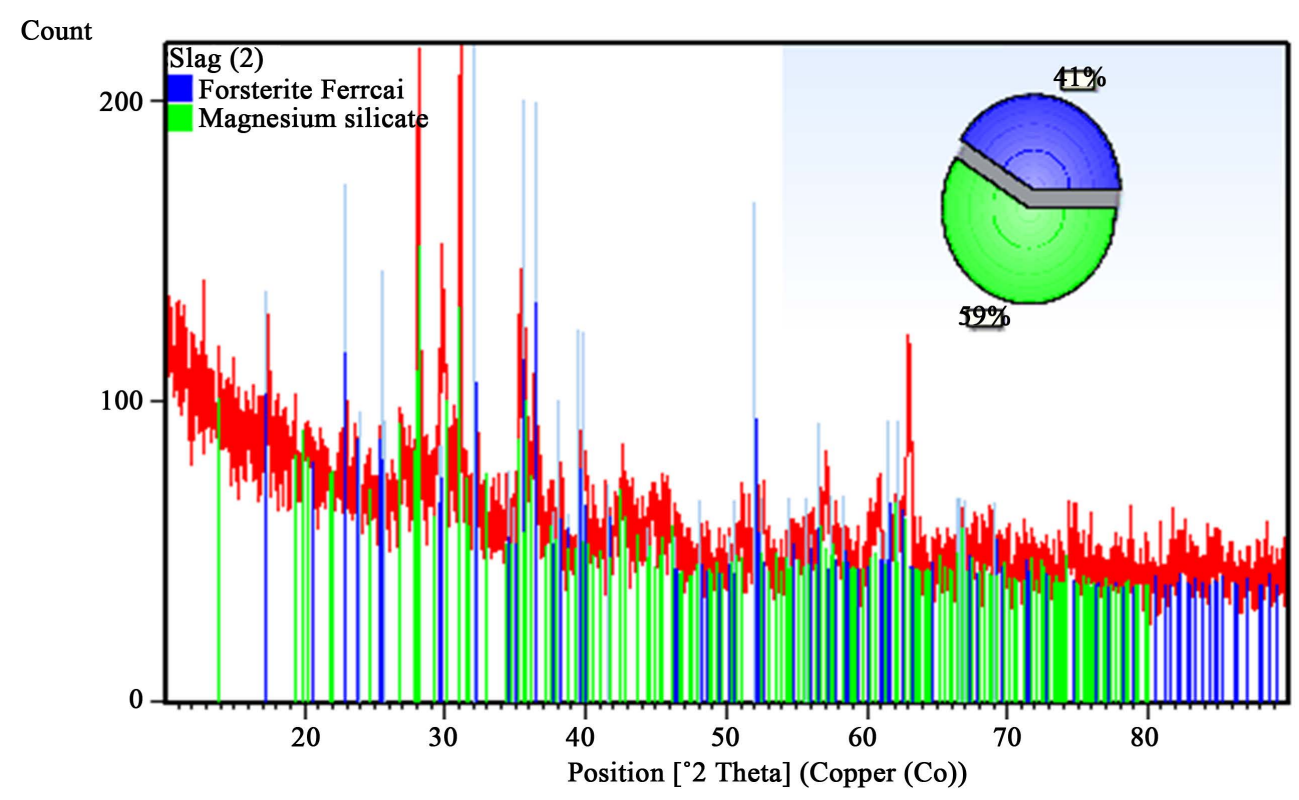

Figure 3. The results of XRD test of the new slag sample.

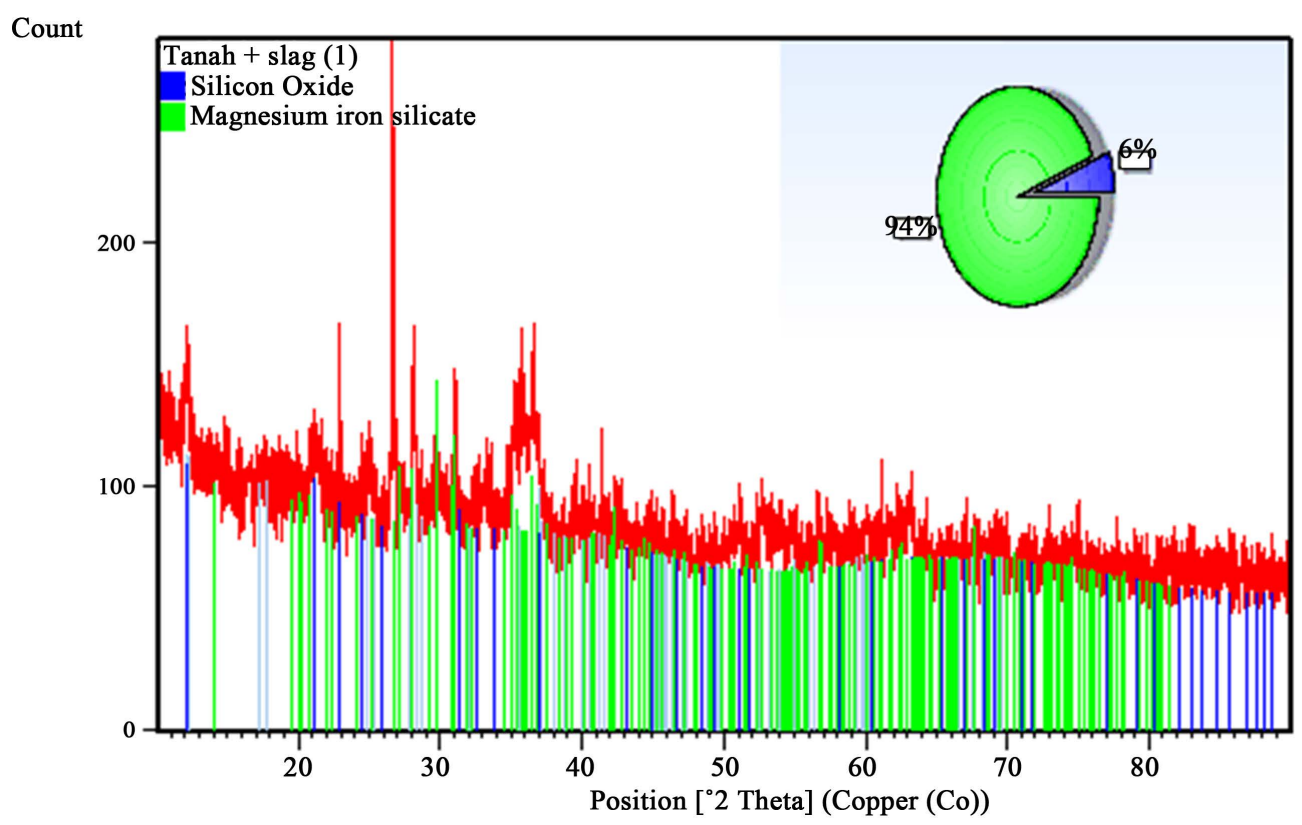

Figure 4. The results of XRD test of the slag sample from reclamation area. 


\section{Conclusions}

The conclusions of this study:

1) The TCLP test results showed that metal content of the new slag sample contained Fe 6775 ppm, Cr 0.64465 ppm and $\mathrm{Pb} 0.0219 \mathrm{ppm}$. Cu and $\mathrm{Cd}$ were not detected. While the results of the CTLP test showed that the slag sample from reclamation area was contained with $3.94 \mathrm{ppm}$ of $\mathrm{Fe}$ and $2.91 \mathrm{ppm}$ of $\mathrm{Cr}$, since the $\mathrm{Pb}, \mathrm{Cu}$, and Cd were not detected. The concentration of Cr was exceeded the quality standard TCLP based on Indonesia Government Regulation No. 18 the year of 1999. (PP no. 18 tahun 1999).

2) The highest elements in the new slag sample are Si and $\mathrm{Mg}$ with percentage of $18.94 \%$ and $15.83 \%$, then followed by $\mathrm{Fe}$ and $\mathrm{Ni}$ with percentages of $5.84 \%$ and $0.014 \%$ respectively. The toxic heavy metals of $\mathrm{Cu}$, $\mathrm{Cr}, \mathrm{Pb}$ and $\mathrm{Co}$ are in a very small percentage, and $\mathrm{Pb}$ is not detected in the slag. The dominant mineral contents in the slag are forsterite $\left(\mathrm{Mg} 1.784 \mathrm{Fe} 0216 \mathrm{SiO}_{4}\right)$ and magnesium silicate $\left(\mathrm{Mg}_{2}\left(\mathrm{Si}_{2} \mathrm{O}_{6}\right)\right)$. Forsterite in the mineral mix is $41 \%$ while the rest of it is magnesium silicate.

3) The slag sample from reclamation area is contained with $\mathrm{Ni}$ in higher concentration than the new slag sample. And also the slag sample from reclamation area is contained with high $\mathrm{SiO}_{2}$ and $\left.\mathrm{Mg}_{2}\left(\mathrm{SiO}_{6}\right)\right)$.

\section{References}

[1] Svana, E. and Ysteb, R. (1990) Production of FeNi from High Iron Nickel Ores. Engineering Division, Norway. USEPA (2007) Method 1311, Standard for TCLP Method.

[2] Demotica, J.S., Amparado Jr., R.F., Malaluan, R.M. and Demayo, C.G. (2012) Characterization and Leaching Assessment of Ferronickel Slag from a Smelting Plant in Iligan City, Philippines. International Journal of Environmental Science and Development, Vol. 3, No. 5.

[3] Julli, M. (1999) Ecotoxicity and Chemistry of Leachates from Blast Furnace and Basic Oxygen Steel Slag. Australasian Journal of Ecotoxicology, Vol. 5, hal. 123-132. PeraturanPemerintahnomor 18 tahun 1999 tentang Baku MutuHasilUji TCLP. 